\title{
Response of physical quality and biochemical characteristics to different maturity stages of Mangifera indica (cv. Amrapali)
}

\author{
Md. Rajibullah Jaman ${ }^{1}$, Md. Fakhrul Hassan ${ }^{1}$, Mahbub Rabbani ${ }^{1}$, Tamal Patra Suvo ${ }^{2 *}$ and \\ Md. Rasel Ahmed ${ }^{3}$
}

${ }^{1}$ Dept. of Horticulture, Patuakhali Science and Technology University (PSTU), Patuakhali-8602 ${ }^{2}$ Dept. of Biochemistry and Food Analysis, Patuakhali Science and Technology University (PSTU), Patuakhali-8602, Bangladesh

${ }^{3}$ Dept. of Horticultur, Bangladesh Agricultural University (BAU), Mymensingh, Bangladsh

$\triangle$ Corresponding author*: shuvopatra [@] gmail.com

Article Received: 22.03.17; Revised: 26.09.17; Published online: 25 November 2017.

\begin{abstract}
Mango fruit consumers often confuse to select exact fruits from markets. A study was conducted to analyze the physical quality and biochemical componentsat different stages ofmango cultivar "Amrapali".The study was conducted at the postharvest laboratory, Department of Horticulture, PSTU during the period from January to December 2015. Stage-1 was marked when the peel color was dark olive green and turning toyellow at the seedand the subsequent maturity stages determined at 2-days intervals as stage-2 was olive, stage-3 was apple green, stage-4 was brown, stage-5 was saddle brown and stage- 6 was dark golden rod in color. At each maturity stages, physical (peel color, firmness and weight loss) and biochemical (anthocyanin content, titratable acidity, $\mathrm{pH}$, total soluble solids, ascorbic acid, reducing sugar, non-reducing sugar and total sugar) maturity indices were determined. The $\mathrm{pH}$ (4.54), anthocyanine content (430 mg/100 g), TSS (24.33\%), reducing sugar (7.56\%), non-reducing sugar (5.84\%) and total sugar (13.40\%) were significantly highest at stage-6 (dark golden rod colour). The titratable acidity (0.30\%) and ascorbic acid (25.29 mg/100 g) were significantly highest at stage-1 (dark olive green). Firmness decreased gradually with the advancement of maturation and flesh color turned dark olive green to dark golden rod. Total soluble solids were increased while TA was gradually decreased with increase of maturity. Dark olive greencolour stage (stage-1) is suitable for harvesting and transportation due to highest physical qualityand dark golden rod colour stage(stage-6) is suitable for consumption due to highest biochemical composition.
\end{abstract}

Key Words: Mangifera indica, Physiological characteristics, Bio-chemicals and Maturity indices

Cite Article: Jaman, M. R., Hassan, M. F., Rabbani, M., Suvo, T. P. and Ahmed, M. R. (2017). Response of physical quality and biochemical characteristics to different maturity stages of Mangifera indica (cv. Amrapali). Journal of Bioscience and Agriculture Research,15(02), 1279-1286.

Crossref: https://doi.org/10.18801/jbar.150217.158

Article distributed under terms of a Creative Common Attribution 4.0 International License. 


\section{Introduction}

Mango (Mangifera indica L.) belongs to Anacardiaceae family, is an economically important and well known fruit crops grown in Bangladesh. It is enriched with a numerous number of varieties. There are about 1600 varieties are found in all over the world while 100 in Bangladesh. Amrapali, Mallika, Langra, Aswina, Fazli, Gopalbhog, Himsagar, Khirsapati, Kishanbhog, Kohinoor, Kuapahari, Mohanbhog, Deshari, Neelumare the well knowncultivars in Bangladesh. On an average $100 \mathrm{~g}$ mango pulp contains $60 \mathrm{kcal}$ energy, protein $0.82 \mathrm{~g}$, total lipid (fat) $0.38 \mathrm{~g}$, carbohydrates $15.0 \mathrm{~g}$, fibre $1.6 \mathrm{~g}$, sugars $13.7 \mathrm{~g}$, calcium $11 \mathrm{mg}$, phosphorus $14 \mathrm{mg}$, iron $0.16 \mathrm{mg}$, potassium $168 \mathrm{mg}$, vitamin C $36.4 \mathrm{mg}$, vitamin A $54 \mu \mathrm{g}$, vitamin $0.90 \mathrm{mg}$, riboflavin $0.04 \mathrm{mg}$, niacin $0.67 \mathrm{mg}$, thiamin $0.03 \mathrm{mg}$, and vitamin B6 $0.12 \mathrm{mg}$ (USDA 2015). Ripe mango pulp contains 16.9\% carbohydrate (Nilish and Banik, 2005). Amrapali is a high yielding and regular bearing variety. Shape of fruit is oblong, medium sized, prominent ventral shoulder, curved back, prominent beak, round apex, thin skin and smooth texture. The pulp is yellow, texture is firm, fibreless, very pleasant aroma, very sweet taste and juicy. Average fruit weight is $220 \mathrm{~g}$. However, very little information on proper maturity colour of fruits is available at growers and consumers level. As a result, fruit consumers confuse to buy fruits from markets due to artificial fruit colour. Therefore objectives of this study were to evaluate the physical quality and chemical characteristics at different colour stages of the fruits and develop a standard maturity color chart of 'Amrapali' mango varieties.

\section{Materials and Methods}

The experiment was carried out at the Postharvest laboratory, Department of Horticulture, Patuakhali Science and Technology University (PSTU), Patuakhali, Bangladesh from January to December 2015. The temperature and relative humidity of the storage room were recorded daily atthe study period bya digital thermo hygrometer (TFA Dostmann GmbH \& Co. KG, Germany). The minimum and maximum temperatures were $24.0^{\circ} \mathrm{C}$ and $33.0^{\circ} \mathrm{C}$, respectively. The minimum and maximum relative humidity was $82 \%$ and $90 \%$, respectively. A total 100 healthy fruits with uniform size, shape and color were collected from the residential area of vice chancellor, PSTU. Fruits were harvested when they attained in light green colour with uniform size and shape. The fruits having no defect were cut off with a sharp knife keeping intact about $2 \mathrm{~cm}$ stalk with them and loaded immediately with care totransferinthe Laboratory. The experiment was laid out in completely randomized design (CRD) with three replications.

\section{Determination of physical characteristics at different stages of the fruits}

Weight loss: Individual fruit was weighted in every alternative day by anelectronic balance. The percentage of weight loss was calculated using the following formula:

Weight loss $(\%)=\frac{\mathrm{W} 1-\mathrm{W} 2}{\mathrm{~W} 1} \times 100$

Where, $\mathrm{W}_{1}=$ Initial weight of the fruit

$\mathrm{W}_{2}=$ Weight of fruits after storage

External peel colour: The fruit peel colourwas determined by “On Color Measure" (an Android Application Software developed by PotatotreeSoft, Version 3.0)where color was identified by using a mobile devicecamera (Plate 01).

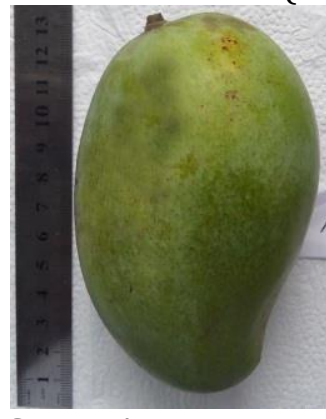

Stage-1

(dark olive green)

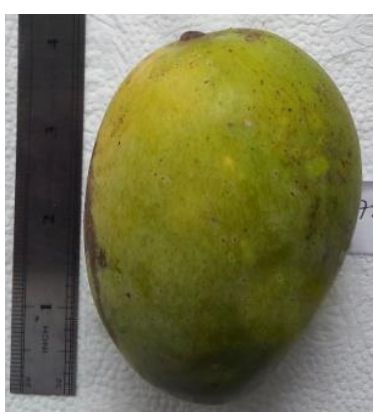

Stage-2

(olive)

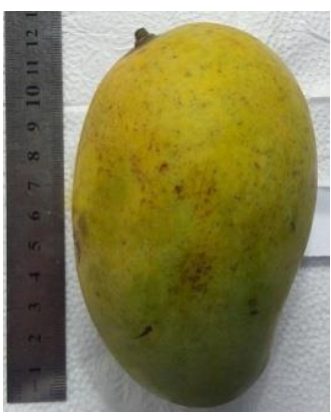

Stage-3

(apple green) 


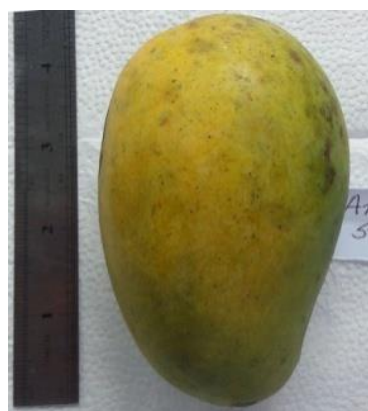

Stage-4

(brown)

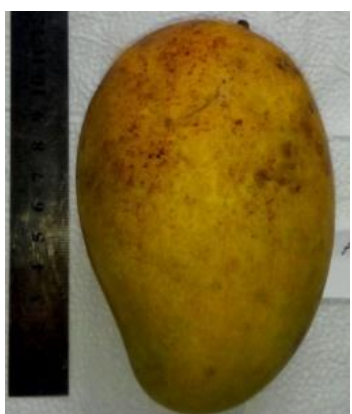

Stage-5

(saddle brown)

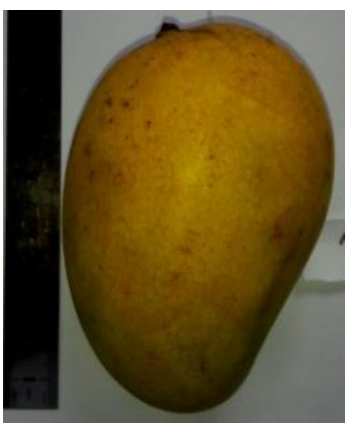

Stage-6

(dark golden rod)

Plate 01. Different maturity stages of Amrapali

Firmness: Firmness of mango was determined by hand feeling using a numerical rating scale of 1-5 (Hasan, 2006) where; $5=$ mature hard, $4=$ sprung, $3=$ between sprung and eating ripe, $2=$ eating ripe and $1=$ over ripe.

\section{Determination of chemical characteristics at different stages of the fruits}

Anthocyanine content: Total Anthocyanine content of peel and the carotinoid content of pulp were determined by the method of Sims and Gamon (2002).

Titratable acidity: Titratable acidity (TA) was determined according to Titration method described By Ranganna (1979) and calculated followed by the formula:

$$
\begin{aligned}
& \text { Titratableacid }(\%) \\
& =\frac{\text { Titre }(\mathrm{mL}) \times \mathrm{NaOH} \text { normality }(0.1 \mathrm{M}) \times \text { Vol. made up }(50 \mathrm{~mL}) \times \text { Citric acid eq. weight }(64 \mathrm{~g}) \times 100}{\text { Volume of sample for titrate }(5 \mathrm{~mL}) \times \text { Weight of sample taken }(10 \mathrm{~g}) \times 1000}
\end{aligned}
$$

pH: Remaining of the filtrated juice from TA determination was used to measure the $\mathrm{pH}$ of the fruit pulp. The $\mathrm{pH}$ was determined by using a glass electrode $\mathrm{pH}$ meter (PHS-25 Precision $\mathrm{pH} / \mathrm{mV}$ meter, Shanghai LIDA Instrument Factory, China)

Total soluble solids (TSS): The percentage of TSS was determined by a digital refractometer (BOE 32195, BOECO, Germany).

Ascorbic acid (Vitamin C): Ascorbic acid was determined according to the dye method (Ranganna, 1979).

Total sugar: Sugar content was determinedby the procedures described by Lane and Eynon (1923).

Standardization of Fehling's solution: $50 \mathrm{ml}$ of both Fehling's solution A and B were mixed in a beakerand $10 \mathrm{ml}$ was taken into a $250 \mathrm{ml}$ conical flask. $25 \mathrm{ml}$ distilled water was added to it. Standard sugar solution was taken in a burette. The conical flask containing mixed Fehling's solution was heated on a hot plate. Three drops of methylene blue indicator solution was added to the solution when it started to boilwithout removing the flask from the hot plate. Mixed Fehling's solution was titrated by standard sugar solution. The end point was indicated by discoloration. Fehling's factor was calculated by using the following formula:

$$
\text { Fehling's factor }(\mathrm{g} \text { of sugar })=\frac{\text { Titre } \times 2.5}{100}
$$

Preparation of sample: Fruit juice $(50 \mathrm{ml})$ was mixed with distilled water $(100 \mathrm{ml})$ and neutral led acetate $(5 \mathrm{ml})$. kept it for ten minutes to homogenize. Solution was transferred to a $250 \mathrm{ml}$ volumetric flaskandthe volume was made up to the mark with distilled water. Solution was then filtered. 
Estimation of reducing sugar: $10 \mathrm{ml}$ of mixed Fehling's solution was taken in a $250 \mathrm{ml}$ conical flask and made $250 \mathrm{ml}$ with distilled water. Purified juice solution (filtrated) was taken in a burette. Conical flask containing mixed Fehling's solution was heated on a hot plate. Three to five drops of methylene blue indicator was added to the flask when boiling started and titrated with solution taken in burette. End point was indicated by discoloration. Percentage of reducing sugar was calculated by following formula:

$$
\begin{aligned}
& \text { Reducing sugar }(\%)=\frac{F \times D \times 100}{T \times W \times 1000} \\
& \text { Where, } \quad \begin{array}{l}
F=\text { Fehling's solution } \\
D=\text { Dilution } \\
\mathrm{T}=\text { Titre, and } \\
W=\text { Weight of sample }
\end{array}
\end{aligned}
$$

Estimation of total invert sugar: $50 \mathrm{ml}$ of purified solution (filtrated) was taken in a $250 \mathrm{ml}$ conical flask. $5 \mathrm{ml}$ citric acid and $50 \mathrm{ml}$ distilled water was added to it. The conical flask containing sugar solution boiled for inversion of sucrose and cooled. Then the solution was transferred to a $250 \mathrm{ml}$ volumetric flask and neutralized by $1 \mathrm{~N} \mathrm{NaOH}$ using phenolphthalein indicator. The volume was made up to the mark with distilled water. The mixed Fehling's solution was titrated as same as reducing sugar. The percentage was also calculated similarly as reducing sugar.

Estimation of non-reducing sugar: Non-reducing sugar was estimated by using the following formula:

Non-reducing sugar $(\%)=$ Total invert sugar $(\%)$ - Reducing sugar $(\%)$

Statistical analysis: The data on different parameters were tabulated and analyzed MSTATCprogramme (Gomez and Gomez, 1984). All the treatment means were calculated and the analysis of variances (ANOVA) was done by Duncan's Multiple Range Test (DMRT). The means were separated by Least Significant Difference (LSD) test at $1 \%$ levels of significance.

\section{Results and Discussion}

\section{Physical characteristics at different stages of the fruits}

\section{Peel colour}

Colour is one of the most important criteria of quality of most fruits. Changes in colour of mango peel dark olive green to dark golden rod are the most obvious changes which occur during storage of fruits (Plate 01).

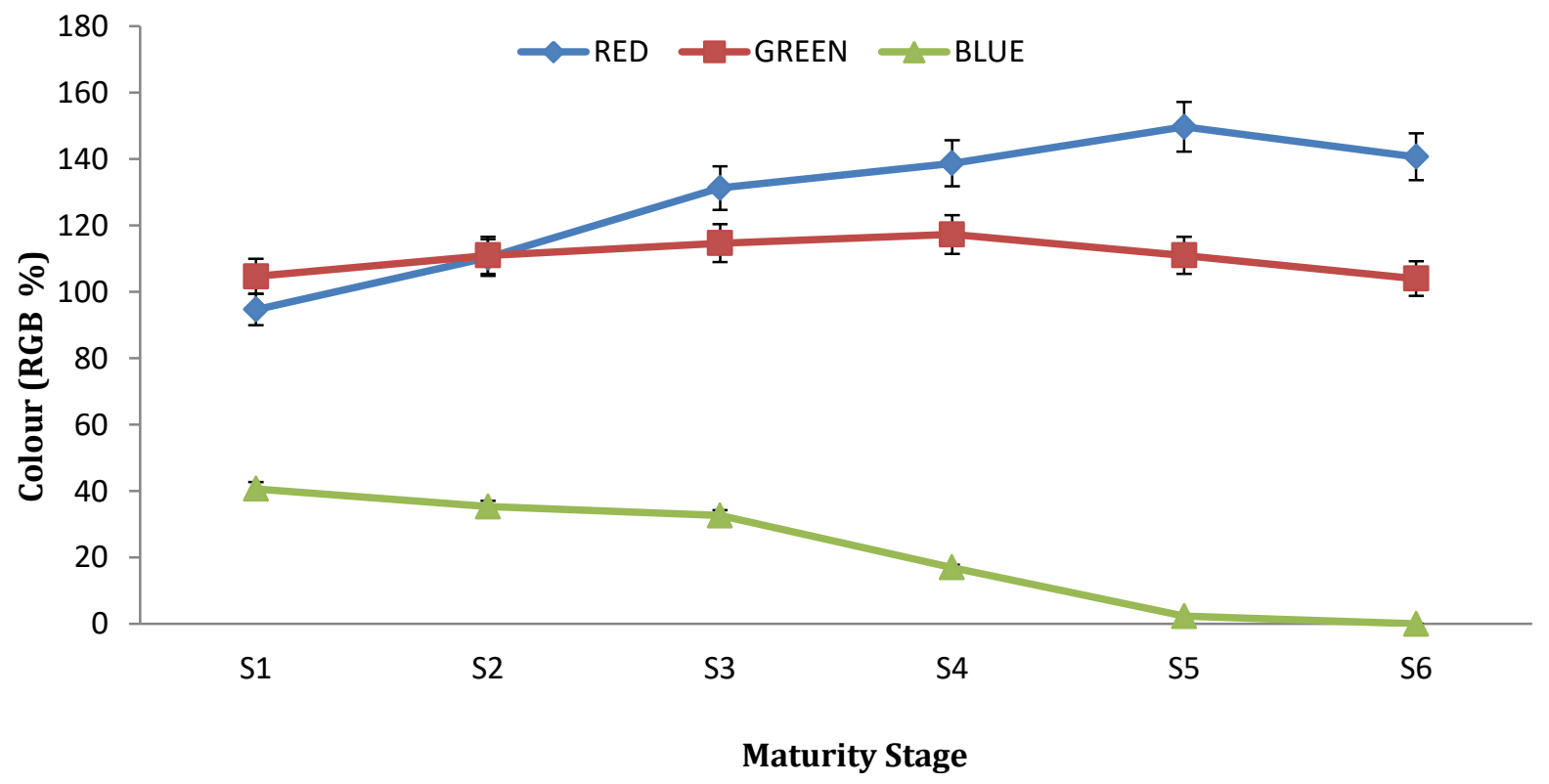

Figure 01. RGB \% of Amrapali at different maturity stages. 
At early stage green $(\mathrm{G})$ colour was prominent and gradually decreased with maturity. At stage-1, red green and blue colorwere $94.67 \%, 104.7 \%$ and $40.67 \%$, respectively. The red (R) colour contain was highest at stage-5 (RGB\%- 150). Then value of RGB\% was decreasing due to deterioration of colour pigment.Change of peel colour during ripening and senescence of fruits involves chlorophyll degradation or qualitative and quantitative alternation of the green pigment into other pigments (Figure 01 and Plate 01).

\section{Firmness}

Firmness is important criteria of fruits quality. Firmness of mango pulp from stage- 1 to stage- 6 is an obvious change during storage.

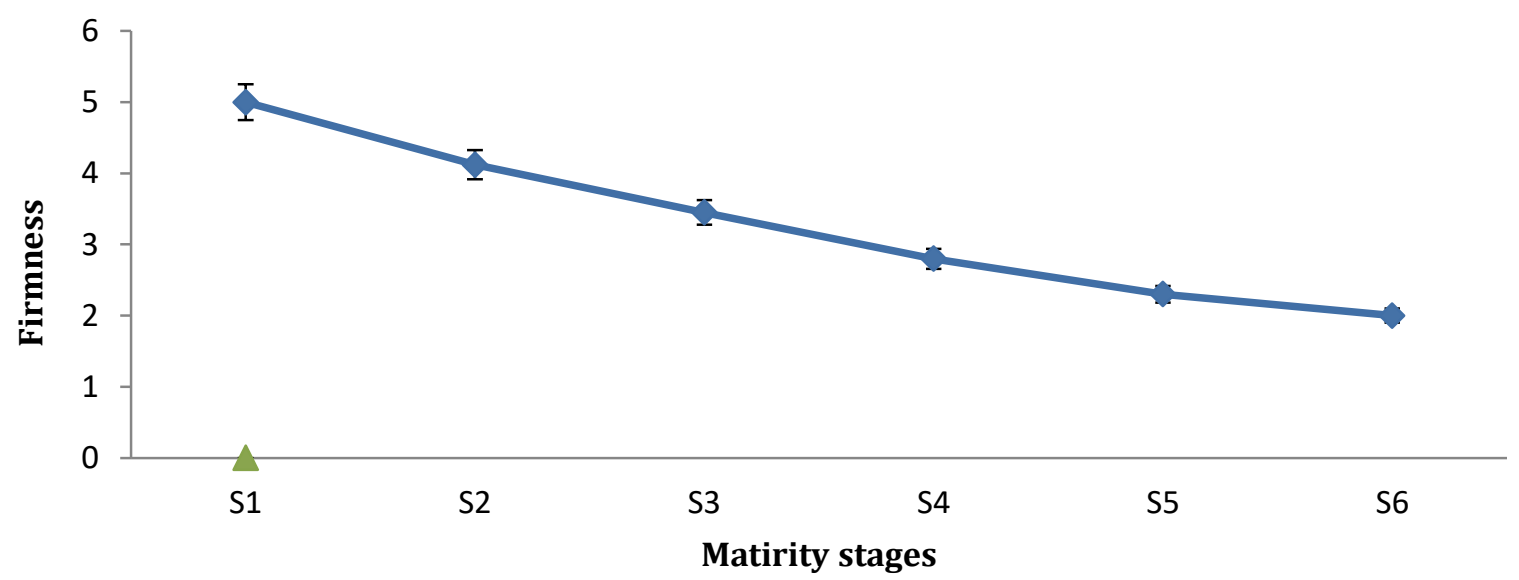

Figure 02. Firmness of Amrapali at different maturity stages.

Significant variation was observed in respect of firmness of mango pulp at different stages (Figure 02). The highest firmness was recorded at stage-1, and then the firmness of mango was decreased due to conversion of starch and pectin into sugars.

During colourand firmness change the pulp becomes softer and sweeter as the ratio of the sugar to starch increased and the characteristics aroma is produced.

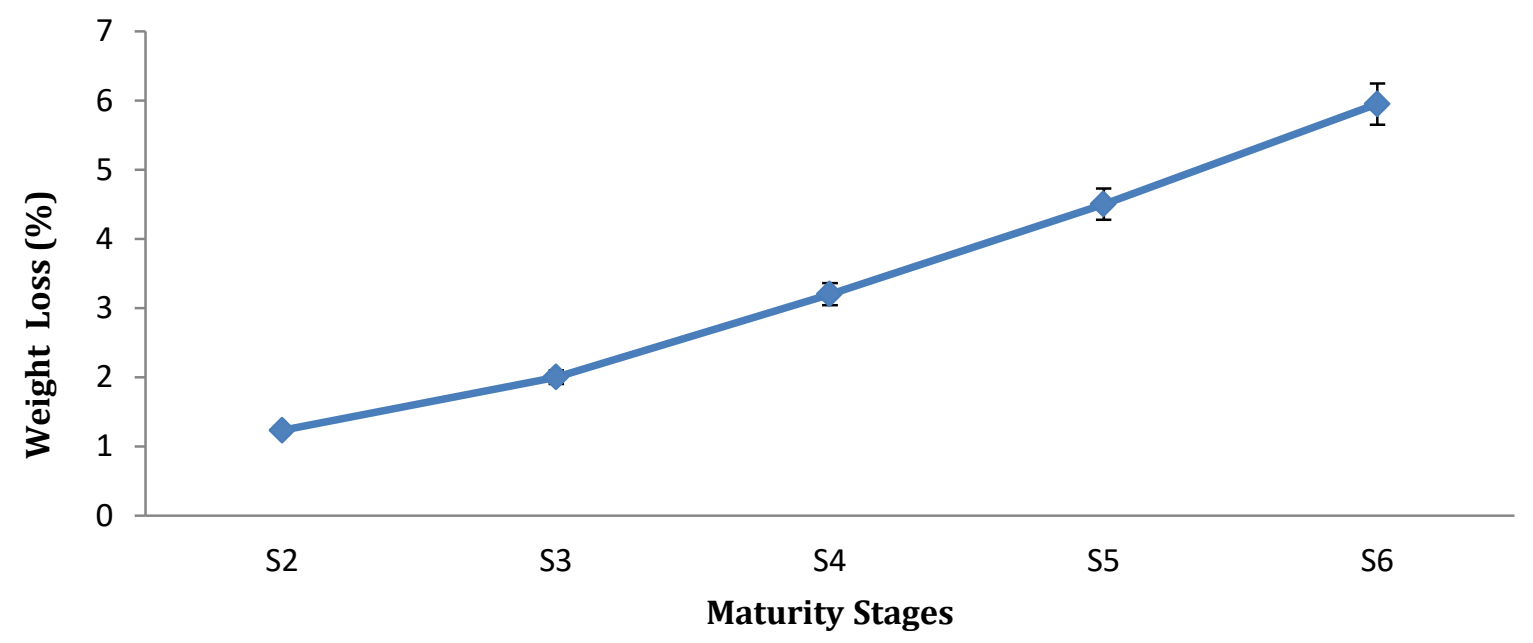

Figure 03. Percent weight loss of Amrapali at different maturity stages.

\section{Weight loss}

Significant variation was observed in total weight loss at different maturity stages of the fruits (Figure 03). The highest weight loss was 5.95\% at stage-6 (Figure 03). Weight loss of the fruits was occurred due to the loss of water from the fruits, microbial decay and storage environment like temperature 
and humidity. High temperature enhanced weight loss but low temperature reduced weight loss during ripening and storage.

\section{Biochemical characteristics at different stages of the fruits}

\section{Total anthocyanin content}

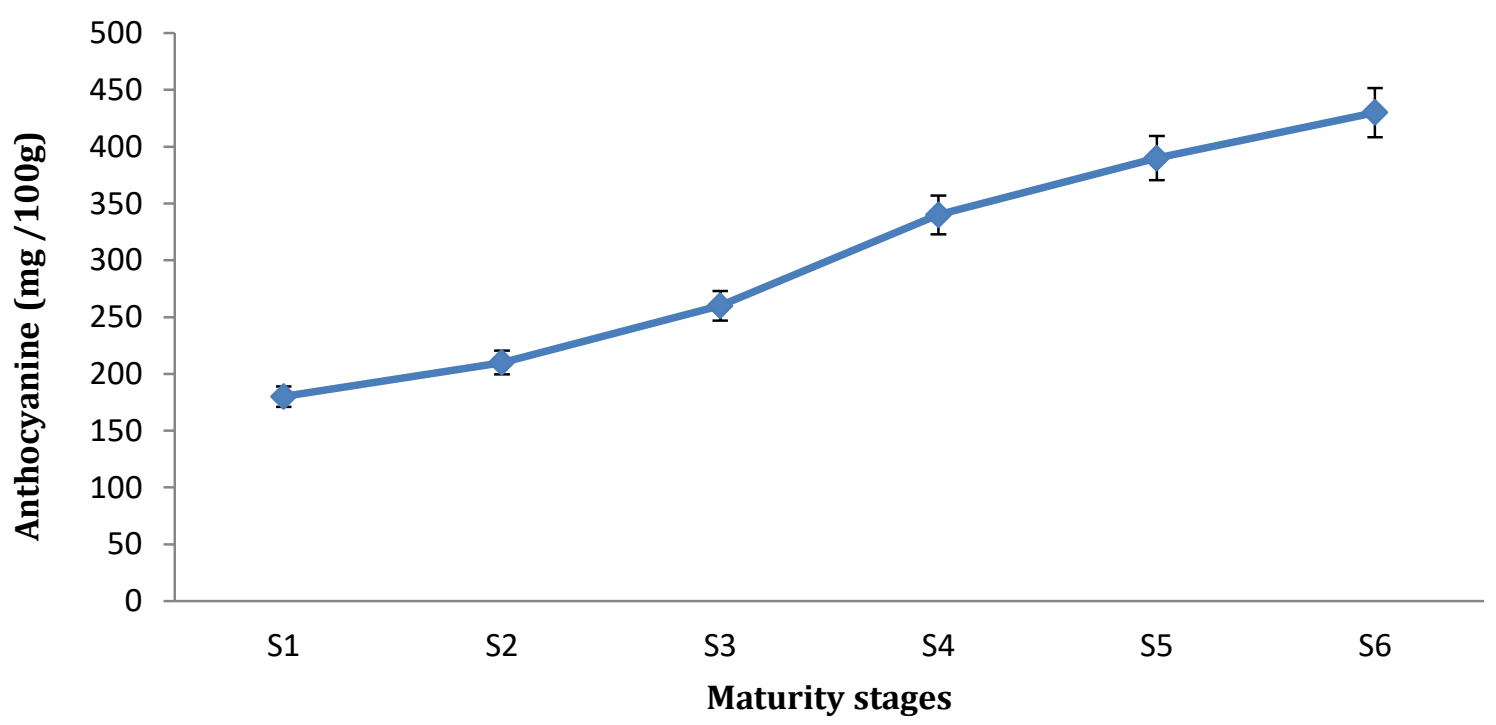

Figure 04. Anthocyanin content in Amrapali mango varieties.

It was found that, the anthocyanin content was more in ripe mango peel and it was found highest at stage-6, $430 \mathrm{mg} / 100 \mathrm{~g}$ (Figure 04).

\section{Titratable acidity}

Titratable acidity content of fruits varied significantly at different stages during storage (Table 01). The highest titratable acidity $(0.31 \%)$ was recorded at satge 1 which was followed by stage- $2(0.28 \%)$ and stage-3 $(0.25 \%)$. Then the titratable acidity was decreased at fully ripen stage i.e., stage- $6(0.17 \%)$. A gradual decrease in titratable acidity with the advancement of maturity may cause due to various enzymatic activities.

\section{pH of fruit juice}

The $\mathrm{pH}$ of the fruit pulp at different stages ranged from 3.96-4.54 at different maturity stages (Table 01). The lowest $\mathrm{pH}$ (3.96) was recorded at stage -1, followed by stage- 2 (4.09) and stage-3 (4.19). The $\mathrm{pH}$ was increased up to stage- 6 significantly and the highest $\mathrm{pH}$ (4.54) wasrecorded at stage-6. Statistically highly significant variation of pulp pH was observed at different stages due to conversion of pectin into sugars.

\section{TSS of fruit juice}

TSS ranged from 17.86-24.33\% at different maturity stages (Table 01). The lowest TSS (17.86\%) was recorded ate stage- 1 , followed by stage- $2(19.23 \%)$ and stage-3 $(19.95 \%)$ while the highest TSS $(24.33 \%)$ was recorded at stage-6. During the development of the flesh of a fruit, in many species, nutrients are deposited as starch, which during the ripening process is transformed into sugars. The progression of the ripening process leads to increasing sugar levels.

\section{Ascorbic acid}

The highest ascorbic acid (25.90 mg) was recorded at stage-1, followed by stage- 2 (21.20 mg) and stage-3 $(20 \mathrm{mg})$ whereas the lowest $(11.60 \mathrm{mg})$ at stage-6 (Table 01). 


\section{Reducing sugar}

Reducing sugar content of fruit ranged from 3.90-7.64\% at different maturity stages (Table 01). Lowest reducing sugar (3.90\%) content was found at stage-1 which was followed by stage-2 (4.20\%) and stage-3 (4.90\%). On the other hand, the highest reducing sugar (7.56\%) was recorded at stage-6. A gradual increase in reducing sugar was observed with the advancement of maturity due to various enzymatic activities.

\section{Non-reducing sugar}

The lowest non-reducing sugar $(2.34 \%)$ was found from stage-1, followed by stage- $2(2.63 \%)$ and stage-3 (3.22\%) while the highest non reducing sugar (5.84\%) was recorded at stage-6 .

\section{Total sugar}

Total fruit sugar content ranged from $6.23-13.40 \%$ at different maturity stages (Table 01). The lowest total sugar $(6.23 \%)$ was recorded at stage-1, followed by stage- $2(6.83 \%)$ and stage-3 $(8.13 \%)$. The highest total sugar $(13.40 \%)$ was recorded at stage- 6 .

Mango pulp contains amylase, invertase and high percentage of starch. Starch accumulation is the main activity of fruit which increases fruit weight. Amylase and invertase in the mango pulp play an important role during the development of mango. The hydrolysis of starch during fruit ripening by hydrolytic enzymes has been reported for mango. Changes in amylase activity in mango fruits during development and after being exposed to chilling temperatures have been reported. Fruit softening during ripening is complex process that presumably involves structural changes in the walls of fruit cells. It is thought that these changes are brought about through the action of cell wall hydrolyses, degrading various wall polymers although other mechanisms may be involved. Activities of all these enzymes increased with degree of maturity.

Table 01. Biochemical characteristics of Amrapaliat different fruit maturity stages

\begin{tabular}{|c|c|c|c|c|c|c|c|}
\hline $\begin{array}{c}\text { Maturity } \\
\text { Stages }\end{array}$ & TA(\%) & TSS(\%) & $\mathrm{AA}(\mathrm{mg})$ & $\mathrm{pH}$ & RS(\%) & $\begin{array}{l}\text { Non- } \\
\text { RS(\%) }\end{array}$ & TS(\%) \\
\hline Stage-1 & $0.30 \mathrm{a}$ & $17.86 \mathrm{~d}$ & $25.90 \mathrm{a}$ & $3.96 \mathrm{f}$ & $3.89 \mathrm{~d}$ & $2.34 \mathrm{e}$ & $6.23 e$ \\
\hline Stage-2 & $0.28 \mathrm{ab}$ & $19.23 \mathrm{~cd}$ & $21.17 b$ & $4.09 \mathrm{e}$ & $4.19 \mathrm{~cd}$ & 2.63de & $6.82 \mathrm{de}$ \\
\hline Stage-3 & $0.26 \mathrm{ab}$ & $19.95 c$ & $20.08 b$ & $4.19 \mathrm{~d}$ & $4.91 \mathrm{bc}$ & $3.21 \mathrm{~cd}$ & $8.13 \mathrm{~cd}$ \\
\hline Stage-4 & $0.23 \mathrm{abc}$ & $22.16 \mathrm{~b}$ & $15.04 \mathrm{c}$ & $4.40 \mathrm{c}$ & $5.23 b$ & $3.45 \mathrm{c}$ & $8.60 \mathrm{c}$ \\
\hline Stage-5 & $0.20 \mathrm{bc}$ & 23.23ab & $12.64 d$ & $4.51 b$ & $7.00 \mathrm{a}$ & $5.16 \mathrm{~b}$ & $12.17 \mathrm{~b}$ \\
\hline Stage-6 & $0.17 \mathrm{c}$ & $24.33 a$ & $11.60 \mathrm{de}$ & $4.54 \mathrm{a}$ & $7.56 a$ & $5.84 \mathrm{a}$ & $13.40 \mathrm{a}$ \\
\hline $\operatorname{LSD}_{(0.01)}$ & 0.076 & 1.38 & 2.31 & 0.03 & 0.91 & 0.72 & 1.51 \\
\hline $\mathrm{CV} \%$ & 15.88 & 2.64 & 5.72 & 7.66 & 6.50 & 7.35 & 11.36 \\
\hline
\end{tabular}

Means in a column followed by the same letter(s) are not significantly different at $1 \%$ level of significance TSS= Total soluble solids; AA=Ascorbic acid; TA= Titratable acidity; RS= Reducing sugar; Non-RS= Non reducing sugar; $\mathrm{TS}=$ Total sugar

\section{Conclusion}

Physical quality is highest at stage-1, i.e., dark olive green. This stage is suitable for harvesting and transportation. Chemical composition is highest at stage-6, i.e., dark golden rod colour and this stage is suitable for consumption. Further studies are suggested on maturity stages.

\section{References}

[1]. Gomez, K. A. and Gomez, A. A. (1984). Statistical Procedures for Agric. Res. John Wiley and Sons, New York. p. 680.

[2]. Hassan, M. K. (2006). Final Report: Postharvest loss Assessment: A study to formulate policy for postharvest loss reduction of fruits and vegetables and socio-economic uplift of the stakeholders. p. 188. 
[3]. Lane, J. H. and Eynon, L. (1923). Method for determination of reducing and non-reducing sugars. J. Soc. Chem. Ind. 42, 32-37.

[4]. Nilesh, B. and Banik, B. C. (2005). Yield and physico-chemical properties of some mango cultivars in new alluvial zone of West Bengal. Environment and Ecology. Calcutta, India: MKK Publication 23. pp. 503-506.

[5]. Rahim, M. A. (2009). Fruits for national economy and poverty reduction. Paper presented at the National Seminar on Fruit Show and Festival. China Bangladesh Friendship Centre, 16 June, 2009.

[6]. Ranganna, S. (1979). Manual of analysis of fruit and vegetable products. Tata Mc Graw Hill publishing company Ltd., New Delhi. p. 634.

[7]. Sims, D. A. and Gamon, J. A. (2002). Relationships between leaf pigment content and spectral reflectance across a wide range of species, leaf structures and developmental stages. Bernard field station, 81, 337-354. https://doi.org/10.1016/S0034-4257(02)00010-X

[8]. USDA (United States Department of Agriculture) (2015). Nutritional Data Base for Standard. Retrieved from https://ndb.nal.usda.gov/ndb/search/list.

\section{HOW TO CITE THIS ARTICLE?}

\section{Crossref: https://doi.org/10.18801/jbar.150217.158}

\section{APA (American Psychological Association)}

Jaman, M. R., Hassan, M. F., Rabbani, M., Suvo, T. P. and Ahmed, M. R. (2017). Response of physical quality and biochemical characteristics to different maturity stages of Mangifera indica (cv. Amrapali). Journal of Bioscience and Agriculture Research,15(02), 1279-1286.

\section{MLA (Modern Language Association)}

Jaman, M. R., Hassan, M. F., Rabbani, M., Suvo, T. P. and Ahmed, M. R. "Response of physical quality and biochemical characteristics to different maturity stages of Mangifera indica (cv. Aamrapali)". Journal of Bioscience and Agriculture Research, 15.02(2017): 1279-1286.

\section{Chicago and or Turabian}

Jaman, M. R., Hassan, M. F., Rabbani, M., Suvo, T. P. and Ahmed, M. R. "Response of physical quality and biochemical characteristics to different maturity stages of Mangifera indica (cv. Aamrapali)". Journal of Bioscience and Agriculture Research,15 no.02(2017):1279-1286.

\section{Journal BiNET | Scientific Publication}

$\checkmark \quad$ Faster processing \& peer review

$\checkmark \quad$ International editorial board

$\checkmark \quad 29$ business days publication

$\checkmark$ Greater audience readership

$\checkmark$ Indexing \&bibliographic integration

$\checkmark \quad$ Social sharing enabled

Submissionor email to submit@journalbinet.com

www.journalbinet.com/article-submission-form.htm 